\title{
Multiple roles of COUP-TFIl in cancer initiation and progression
}

\author{
Lacey M Litchfield and Carolyn M Klinge \\ Department of Biochemistry and Molecular Biology, Center for Genetics and Molecular Medicine, University of Louisville School of Medicine, Louisville, Kentucky, USA
}

(Correspondence should be addressed to C M Klinge; Email: carolyn.klinge@louisville.edu)

\begin{abstract}
Chicken ovalbumin upstream promoter transcription factor II (COUP-TFII) is an orphan nuclear receptor that acts as a transcriptional activator or repressor in a cell type-dependent manner. Best characterized for its role in the regulation of angiogenesis during mouse development, COUP-TFII also plays important roles in glucose metabolism and cancer. Expression of COUP-TFII is altered in various endocrine conditions. Cell type-specific functions and the regulation of COUP-TFIl expression result in its varying physiological and pathological actions in diverse systems. Evidence will be reviewed for oncogenic and tumor-suppressive functions of COUP-TFII, with roles in angiogenesis, metastasis, steroidogenesis, and endocrine sensitivity of breast cancer described. The applicability of current data to our understanding of the role of COUP-TFII in cancer will be discussed.
\end{abstract}

Journal of Molecular Endocrinology (2012) 49, R135-R148

\section{Introduction}

Steroid hormones and nuclear receptor (NR) ligands play critical roles in cancer initiation and progression, and their antagonists have proven efficacy in the treatment and prevention of cancers. This is most notable in breast and prostate cancers and the use of alltrans retinoic acid (RA) for acute promyelocytic leukemia (Risbridger et al. 2010, Siddikuzzaman et al. 2011). Steroid/NRs act as ligand-activated transcription factors to either positively or negatively regulate gene expression (Stanisic et al. 2010, Ahmad \& Kumar 2011). Activation of NRs occurs through binding a variety of ligands including hormones and vitamins/retinoids. NRs have physiological roles to modulate gene expression during development and growth. As alteration of basal gene expression leads to many pathogenic outcomes, including cancer, maintenance of normal gene expression by NRs is vital. One such critical NR is chicken ovalbumin upstream promoter transcription factor II (COUP-TFII). From the time of the identification of the COUP-TF family in 1986 (Sagami et al. 1986), the many functions of COUP-TFs have continued to be explored. The role of COUP-TFII in cancer is widely debated with evidence linking COUP-TFII to both tumor-suppressive and oncogenic functions. This review will explore both the regulation and function of COUP-TFII and its connections to cancer.

\section{COUP-TFI and COUP-TFII}

The COUP-TF family consists of two highly homologous subtypes, COUP-TFI and COUP-TFII, located on human chromosomes 5 and 15 respectively (Fig. 1). COUP-TFs have been previously reviewed (Tsai \& Tsai 1997, Lin et al. 2011), but not in the specific context of separating COUP-TFI and COUP-TFII in cancer. COUP-TFs are ancient NRs and are located close to retinoid X receptors (RXRs) in the evolutionary tree (Thornton 2001, Thornton et al. 2003). As evolutionarily conserved transcription factors, COUP-TFs have major roles in development. The importance of COUPTFII expression is evidenced by studies in knockout mice (Pereira et al. 1999). Homozygous mutation of COUP-TFII (Nr2f2) leads to embryonic lethality due to impaired angiogenesis and heart defects, resulting in hemorrhage and edema. These effects may in part be explained by the reduction in angiopoietin-1 (Ang-1) expression in COUP-TFII-null mice (Pereira et al. 1999). Other important embryonic roles for COUPTFII include regulation of limb growth and muscle development (Lee et al. 2004). COUP-TFIInull mice display a reduction in expression of $L b x 1$, a protein required for proper muscle precursor cell migration, and in myogenin, which is necessary for muscle cell differentiation (Lee et al. 2004, Vasyutina \& Birchmeier 2006).

DOI: 10.1530/JME-12-0144 Online version via http://www.endocrinology-journals.org 


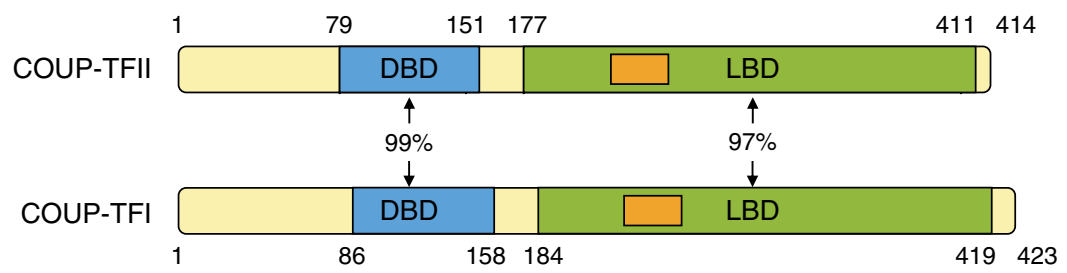

Figure 1 Comparison of COUP-TFI and COUP-TFI protein homology. COUP-TFI (NP_005645.1) and COUP-TFII (NP_066285.1) amino acid sequences were obtained from the National Center for Biotechnology Information. The COUP-TF DNA binding domains (DBD) and ligand-binding domains (LBD) share 99 and 97\% amino acid homology respectively. Positions noted as important in coactivator recognition are shown in orange.

Based on the high-sequence identity in their DNA binding domains (Fig. 1), we anticipate that COUP-TFI and COUP-TFII regulate the same genes. However, this has not been empirically tested and it is worth noting that the N-terminus is divergent (Fig. 1) and immunoprecipitation studies indicate differences in proteins interacting with COUP-TFI (Zhang et al. 2009) and COUP-TFII (Litchfield et al. 2012), although, again, this has not been systematically studied in cells in which both are expressed. COUP-TFI and COUP-TFII may have divergent functions in certain contexts as well. Differences in COUP-TFI and COUP-TFII function in breast cancer endocrine sensitivity, for example, have also been identified (Riggs $e$ al. 2006). This review will focus specifically on COUP-TFII.

\section{COUP-TFII regulation of gene expression}

\section{Mechanisms of regulation}

COUP-TFII can activate or repress gene expression in both a tissue-specific and gene-specific manner through mechanisms involving direct binding to DNA response elements or binding to other transcription factors. Through binding to $5^{\prime}$-AGGTCA-3' direct repeats (DRs) with variable spacing (Kliewer et al. 1992), COUP-TFII modulates the expression of target genes. Specific genes upon which COUP-TFII activates transcription include RA receptor $\beta 2$ (RAR $\beta 2, R A R B 2$; Lin et al. 2000, Litchfield et al. 2012), phosphoenolpyruvate carboxykinase (PEPCK, PCK1; De Martino et al. 2004b), NGFI-A (Egr1; Pipaon et al. 1999, Kruse et al. 2008), and cholesterol $7 \alpha$-hydroxylase (CYP7A1; Stroup \& Chiang 2000). COUP-TFII action may be potentiated by interaction with coactivators such as steroid receptor coactivator family members SRC-1/NCOA1, SRC-2/ NCOA2, and SRC-3/NCOA3 (Pipaon et al. 1999, Kruse et al. 2008), as well as PGC1 $\alpha$ (Kruse et al. 2008), p300/ CBP (Pipaon et al. 1999), orphan receptor coactivator (ORCA; Marcus et al. 1996), and nucleolin (Litchfield et al. 2012). DNA binding of COUP-TFII can promote the binding of a second transcription factor, further activating gene transcription. This occurs for both the PCK1 and Cyp7a1 genes, where COUP-TFII binding to the promoter recruits binding of glucocorticoid receptor (GR) to enhance gene expression (De Martino et al. 2004a,b). COUP-TFII can also bind to Sp1 sites to cooperatively activate gene expression, as was reported for regulation of Otx2 expression during morphogenesis in the mouse eye (Tang et al. 2010).

Alternatively, binding of COUP-TFII to DRs may result in repression of gene expression. In the mechanism of 'active repression,' COUP-TFII binding results in recruitment of corepressors, i.e. nuclear corepressor (NCoR; Bailey et al. 1997) and silencing mediator of retinoid and thyroid receptors (SMRTs; Shibata et al. 1997, Okamura et al. 2009), resulting in repressed chromatin structure and a corresponding blockade of target gene transcriptional activation. COUP-TFII interaction with SMRT represses PPAR 1 (Pparg1) and PPAR 2 (Pparg2) expression to suppress adipogenesis (Okamura et al. 2009). Repression of the human oxytocin promoter by COUP-TFII binding has also been reported (Chu \& Zingg 1997). COUP-TFII represses PAX6 expression in the retina via binding to a DR1 site (TGTTCACAGTCCA; Tang et al. 2010).

Through an alternative mechanism of transrepression, COUP-TFII can interact with other NRs and transcription factors to inhibit their normal transcriptional activity. Examples of this include inhibition of ER- and GR-induced gene expression in a gene-specific manner (Klinge et al. 1997, De Martino et al. 2004b). COUP-TFII can also repress AP-1 signaling through interaction with c-Jun (Lin et al. 2002). Interaction of COUP-TFII with Runx2 inhibits osteoblast differentiation via blocking Runx2 binding to the osteocalcin promoter (Lee et al. 2012). Other mechanisms of repression involve the modulation of ER, RXR, PPAR, and VDR activity by competing for DNA response element binding or heterodimerization with the class II heterodimeric partner RXR (Cooney et al. 1993). 

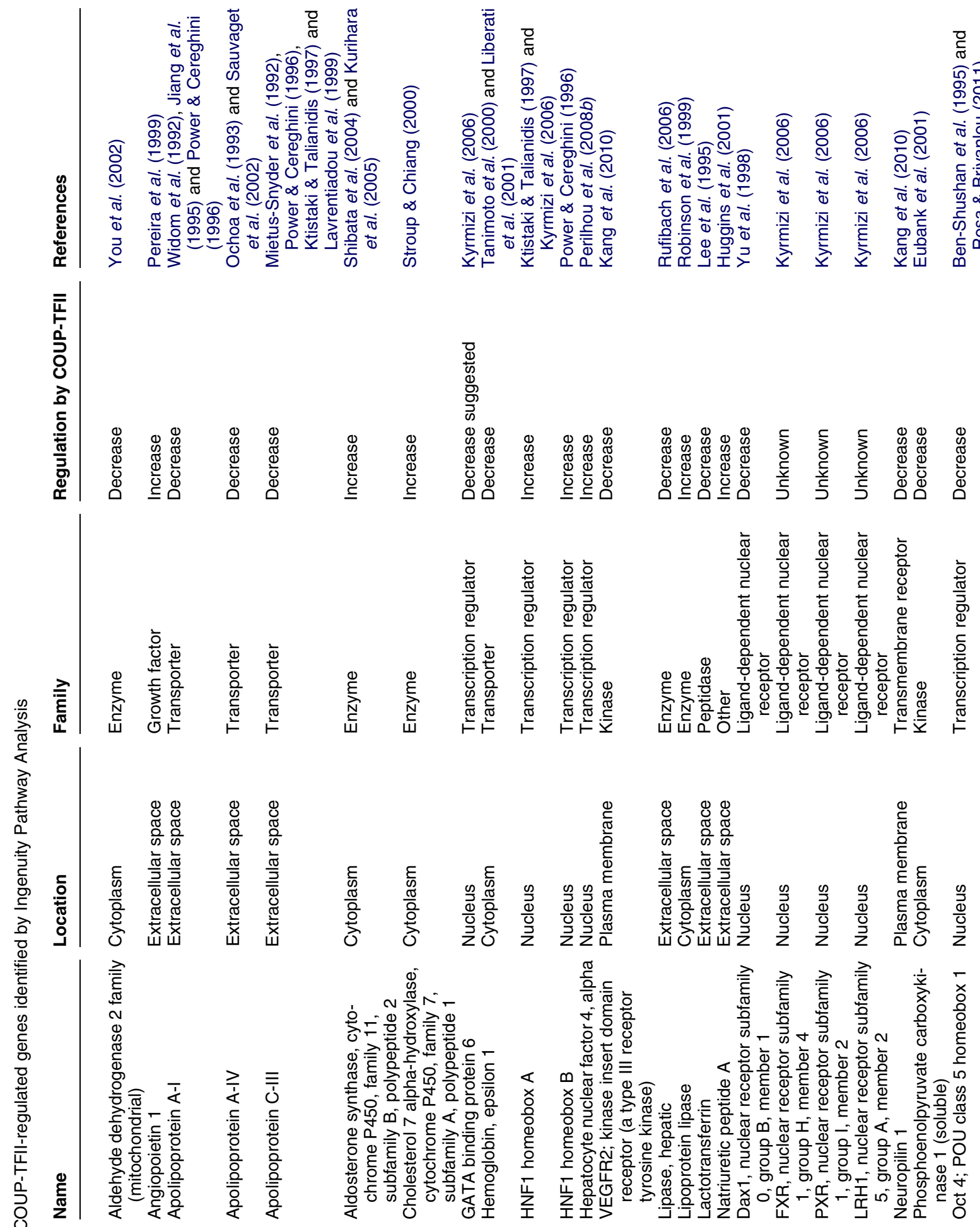

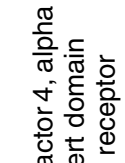
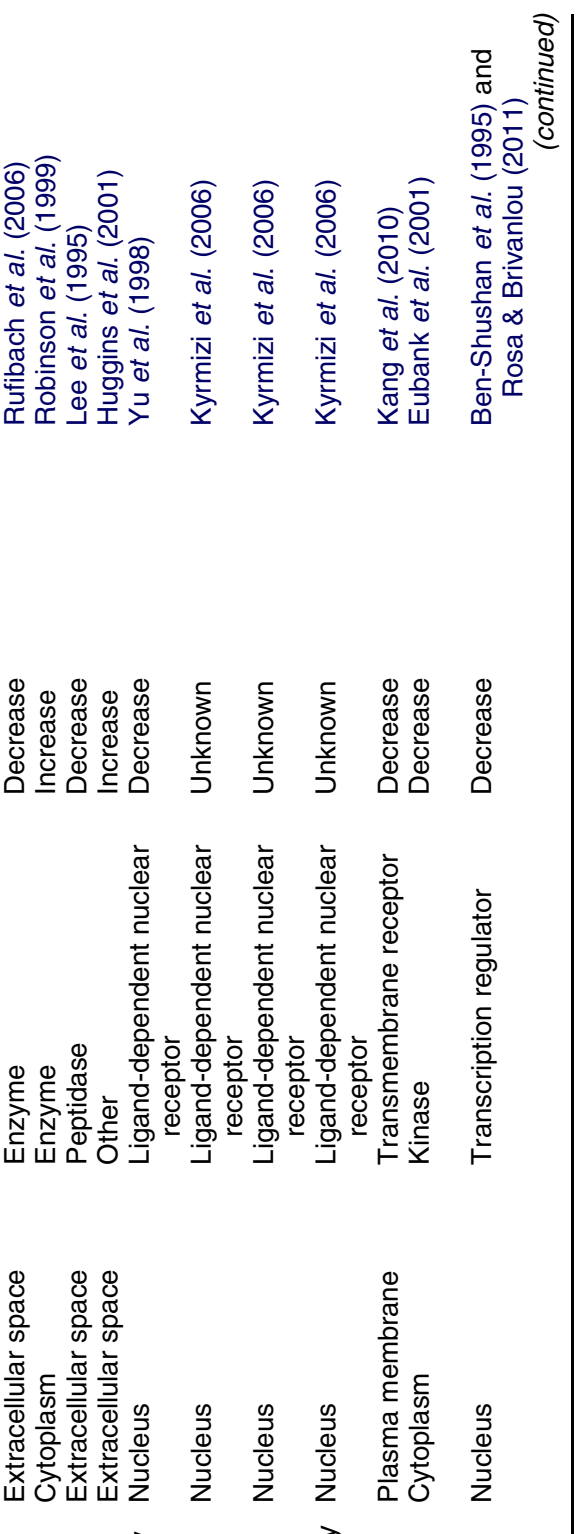

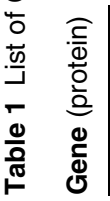

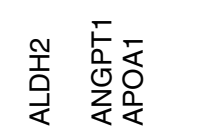

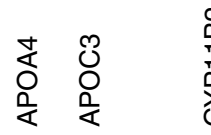

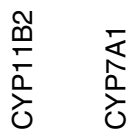

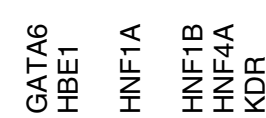

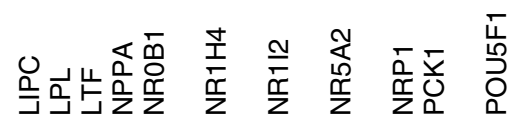




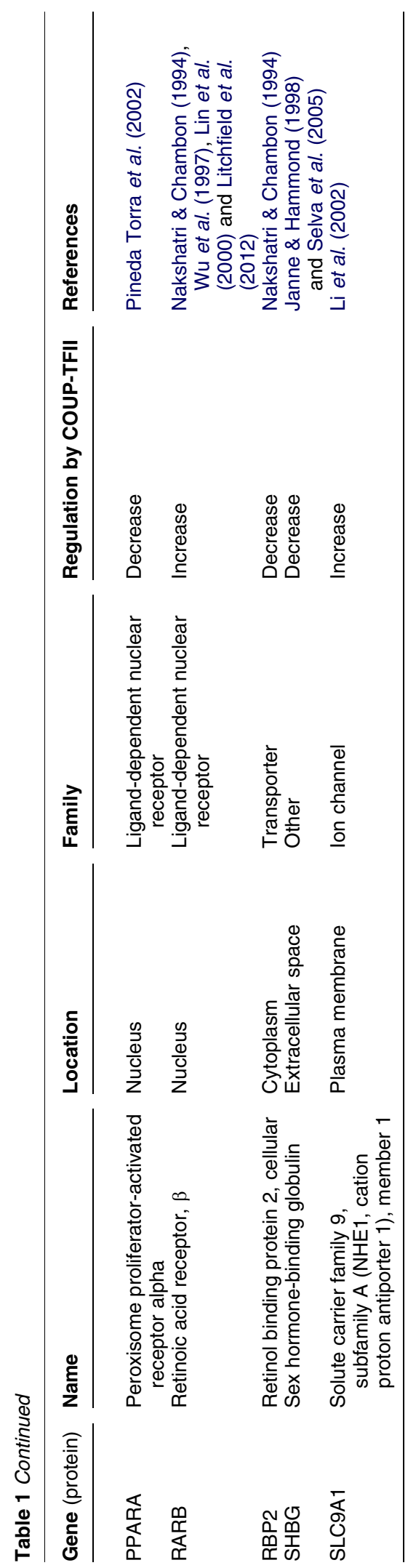

\section{Ingenuity Pathway Analysis}

As summarized here, COUP-TFII regulates the expression of diverse gene targets. Table 1 contains a list of known COUP-TFII targets as identified using Ingenuity Pathway Analysis (IPA; Ingenuity Systems, www.ingenuity.com). These targets are also displayed in Fig. 2. COUP-TFII has varying effects on expression of other NRs and transcription factors. COUP-TFII increased the expression of HNF1 $\alpha$ (Ktistaki \& Talianidis 1997), HNF1 $\beta$ (Power \& Cereghini 1996), HNF4 $\alpha$ (Perilhou et al. 2008b), and RAR $\beta$ (Wu et al. 1997, Lin et al. 2000, Litchfield et al. 2012), while it decreased the expression of Oct4 (Ben-Shushan et al. 1995, Rosa \& Brivanlou 2011), Dax1 (Yu et al. 1998), and PPAR $\alpha$ (Pineda Torra et al. 2002). As previously described, COUP-TFII has well-known functions in repressing the transcriptional activity of other NRs and transcription factors. Although COUP-TFII increases HNF4 expression, other reports highlight the repression of HNF4 function by COUP-TFII. Specifically, COUP-TFII decreases transcriptional activation of $A L D H 2$ (You et al. 2002) and retinol binding protein 2 (RBP2; Nakshatri \& Chambon 1994) by HNF4. The HNF4 activation of hepatic lipase is suppressed by COUP-TFII (Rufibach et al. 2006), while lipoprotein lipase expression is induced by COUP-TFII synergistically with PPAR $\gamma$ (Robinson et al. 1999), part of the many of reported functions of COUP-TFII in the cholesterol-processing pathway. A similar response occurs for apolipoproteins A-I, A-IV, and C-III, where COUP-TFII represses the RXR $\alpha$-mediated expression of APOA-I (Widom et al. 1992, Jiang et al. 1995, Power \& Cereghini 1996) and HNF4-mediated expression of APOA-IV (Ochoa et al. 1993, Sauvaget et al. 2002) and APOC-III (MietusSnyder et al. 1992, Power \& Cereghini 1996, Ktistaki \& Talianidis 1997, Lavrentiadou et al. 1999). HNF4 and COUP-TFII binding to the sex hormone binding globulin $(S h b g)$ promoter was reported in murine Sertoli cells (Selva et al. 2005). SHBG expression is increased by HNF4 and suppressed by COUP-TF in HepG2 hepatoblastoma cells (Janne \& Hammond 1998). Decreased SHBG expression is indicative of metabolic syndrome and may result in increased plasma androgen and estrogen levels, although the precise connection of COUP-TFII to these phenotypes has not been investigated (Hammond 2011).

Although COUP-TFII is classically known for its role in transrepression, COUP-TFII may also enhance the effect of a second NR. Induction of cytochrome P450 family members cholesterol $7 \alpha$-hydroxylase CYP7A1 (Stroup \& Chiang 2000) and aldosterone synthase CYP11B2 (Shibata et al. 2004, Kurihara et al. 2005) by COUP-TFII was reported, with COUP-TFII and HNF4 acting to synergistically activate CYP7A1 (Stroup 


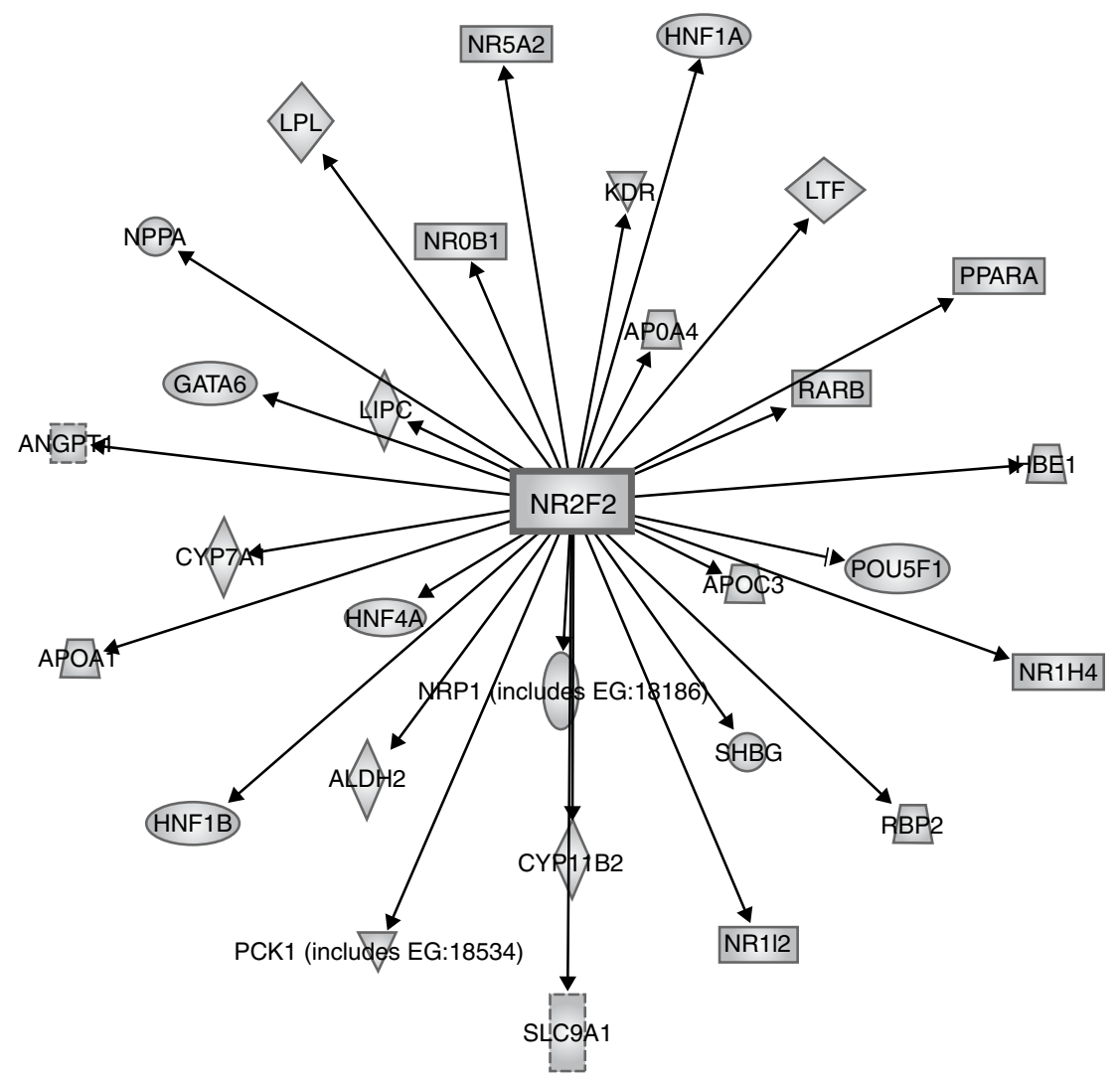

Figure 2 COUP-TFII target genes. COUP-TFII has been reported to modulate the expression of a variety of target genes both positively and negatively. A list of COUP-TFII target genes and corresponding network pathway was generated using Ingenuity Pathway Analysis (IPA; Ingenuity Systems, www.ingenuity.com).

\& Chiang 2000). CYP7A1 catalyzes the first step in the conversion of cholesterol to bile acid (Stroup \& Chiang 2000), while CYP11B2 catalyzes the final steps of aldosterone synthesis (Kurihara et al. 2005), implying that COUP-TFII transcriptional activation would increase the production of bile acid and aldosterone.

As shown in Table 1 and Fig. 2, COUP-TFII opposes PPAR $\gamma /$ RXR activation of PEPCK transcription in preadipocytes/fibroblasts, a result that was proposed to suppress adipogenesis (Eubank et al. 2001). COUP-TF also inhibited 9-cis RA/RXR-induced activation of the lactotransferrin promoter in transiently transfected ZR-75-1 and Hs578T breast cancer cells apparently by competing for DNA binding to a composite RARE/ERE in the gene promoter (Lee et al. 1995). Concurrent binding of COUP-TFII and NF-Y to the hemoglobin epsilon promoter leads to a repression of gene expression (Liberati et al. 2001). In addition to the targets identified by IPA, COUP-TF was reported to play a dual regulatory role in the transcriptional regulation of the mitochondrial HMG-CoA synthase gene: alone COUP-TFI stimulated reporter gene activity from the HMG-CoA synthase promoter in transiently transfected
HepG2 human hepatoma and rat Leydig tumor R2C cells, but it inhibited PPAR $\alpha$-stimulated transcriptional activity by competing for the same DNA binding site (Rodriguez et al. 1997).

Some of the IPA-identified COUP-TFII target gene relationships and mechanisms remain to be fully elucidated. In a study of the transcriptional regulation of murine hepatic development, COUP-TFII occupancy of Gata6, Fxr (Nr1h4), Pxr (Nr1i2), and Lrh1 (Nr5a2) promoters, as determined by chromatin immunoprecipitation (ChIP) assay, was reported during the postnatal period (Kyrmizi et al. 2006). While an inhibitory relationship was suggested for the effect of COUP-TFII on GATA6, the effect on FXR, PXR, and LRH1 expression is not yet known (Kyrmizi et al. 2006). Several other target genes have been identified that highlight the critical function of COUP-TFII in the vascular system. These include an increase in Ang-1 (Pereira et al. 1999) and natriuretic peptide A (Huggins et al. 2001) by COUP-TFII and a decrease in VEGFR2 and neuropilin 1 (Kang et al. 2010). COUP-TFII enhances expression of the NHE1 solute exchanger (Fernandez-Rachubinski \& Fliegel 2001, Li et al. 2002). 
In summary, as indicated by the IPA (Fig. 2) and consistent with previous reports, COUP-TFII plays a role in many downstream pathways and may either activate or suppress gene expression.

\section{Role in the RA pathway}

COUP-TFs are classified as orphan members of the NR superfamily because their endogenous ligand(s) is not known. However, Kruse et al. (2008) demonstrated in silico binding of all-trans (atRA) and 9-cis (9cRA) RA to the crystal structure of the COUP-TFII ligandbinding domain (LBD). RA released the COUP-TFII LBD from the autorepressed conformation. While the investigators did not directly test binding of all-trans or 9-cis RA to COUP-TFII, they demonstrated that treatment with atRA or 9cRA increased COUP-TFII interaction with the coactivator SRC-3, with an EC $_{50}$ of $10-30 \mu \mathrm{M}$. In agreement with this data, addition of $20 \mu \mathrm{M}$ atRA or 9cRA led to COUP-TFII's activation of a NGFI-A-luciferase reporter (Kruse et al. 2008). Although these concentrations of atRA and 9cRA are greater than the physiological concentration of these retinoids, this finding provides novel insight into the ligand binding ability of COUP-TFII. Indeed, the function of this activation can be seen in the regulation of RAR $\beta 2$ by COUP-TFII, as COUP-TFII activation of RAR $\beta 2$ expression is increased with the addition of alltrans RA (Lin et al. 2000, Litchfield et al. 2012). Treatment of MCF-7 breast cancer cells with atRA also increased COUP-TFII-binding to the RARB2 promoter in a ChIP assay (Litchfield et al. 2012). RA induces the expression of COUP-TFII in certain breast cancer cell lines (e.g. T47D and ZR-75) but not others (e.g. MCF-7 and MDA-MB-231) (Fig. 3) (Nakshatri et al. 2000, Litchfield et al. 2012). This indicates a potential

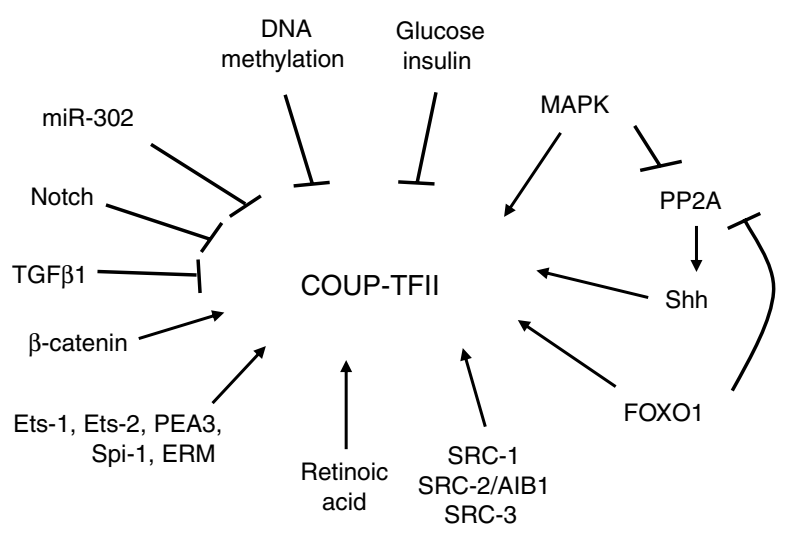

Figure 3 Regulation of COUP-TFII expression. COUP-TFII expression has been shown to be modulated both transcriptionally and posttranscriptionally by a variety of transcription factors, signaling pathways, and various molecules, as shown here. feed-forward loop, as treatment with RA may increase both the expression and activation of COUP-TFII, with downstream effects on RAR.

\section{Regulation of COUP-TFII expression}

\section{Tissue-specific regulation in humans}

COUP-TFII has a widespread tissue distribution, with detectable expression in every human tissue type examined (Suzuki et al. 2000a). The regulation of COUP-TFII expression is tissue and cell-type specific and can be modulated both transcriptionally and posttranscriptionally (Fig. 3). Hyperinsulinemia is a risk for breast cancer (Gunter et al. 2009, Ferguson et al. 2012). COUP-TFII expression was repressed by insulin and glucose in the liver and pancreas of C57BL6/J mice and in mouse primary hepatic and pancreatic cell culture (Perilhou et al. 2008a). By contrast, we found that insulin treatment had no effect on COUP-TFII expression in MCF-7 and T47D breast cancer cells (Fig. 4). The lack of alteration in COUPTFII expression with insulin in breast cancer cells highlights the importance of cell-specific regulation of COUP-TFII expression. There are currently no reports on the effect of insulin on COUP-TFII expression in other cancers.

\section{MicroRNA regulation}

MicroRNA (miRNA) expression is altered in a variety of conditions and disease states, including cancer, and results in important posttranscriptional regulation of crucial proteins (Lovat et al. 2011). While 115 miRNAs are predicted to target NR2F2 (http:/ / cometa.tigem.it/ site/index.php), only one miRNA has been verified. miRNA-302 directly represses COUP-TFII expression in human embryonic stem cells (Rosa \& Brivanlou 2011). Regulation of COUP-TFII expression by miRNA has not yet been reported in cancer cells.

\section{DNA methylation}

Methylation at CpG islands can result in suppression of gene transcription and is known to be a hallmark of cancer progression. DNA methylation may also occur at intragenic and intergenic sites, as well as at the promoter (Deaton \& Bird 2011, Shenker \& Flanagan 2012). Specifically, COUP-TFII has been found to be methylated in many cancers, including mantle cell lymphoma, acute myeloid leukemia, salivary gland adenoid cystic carcinoma, pancreatic adenocarcinoma, colon cancer, breast cancer ductal carcinoma in situ, as well as a tamoxifen-resistant breast cancer cell line (Fan et al. 2006, Irizarry et al. 2009, Tommasi et al. 2009, 

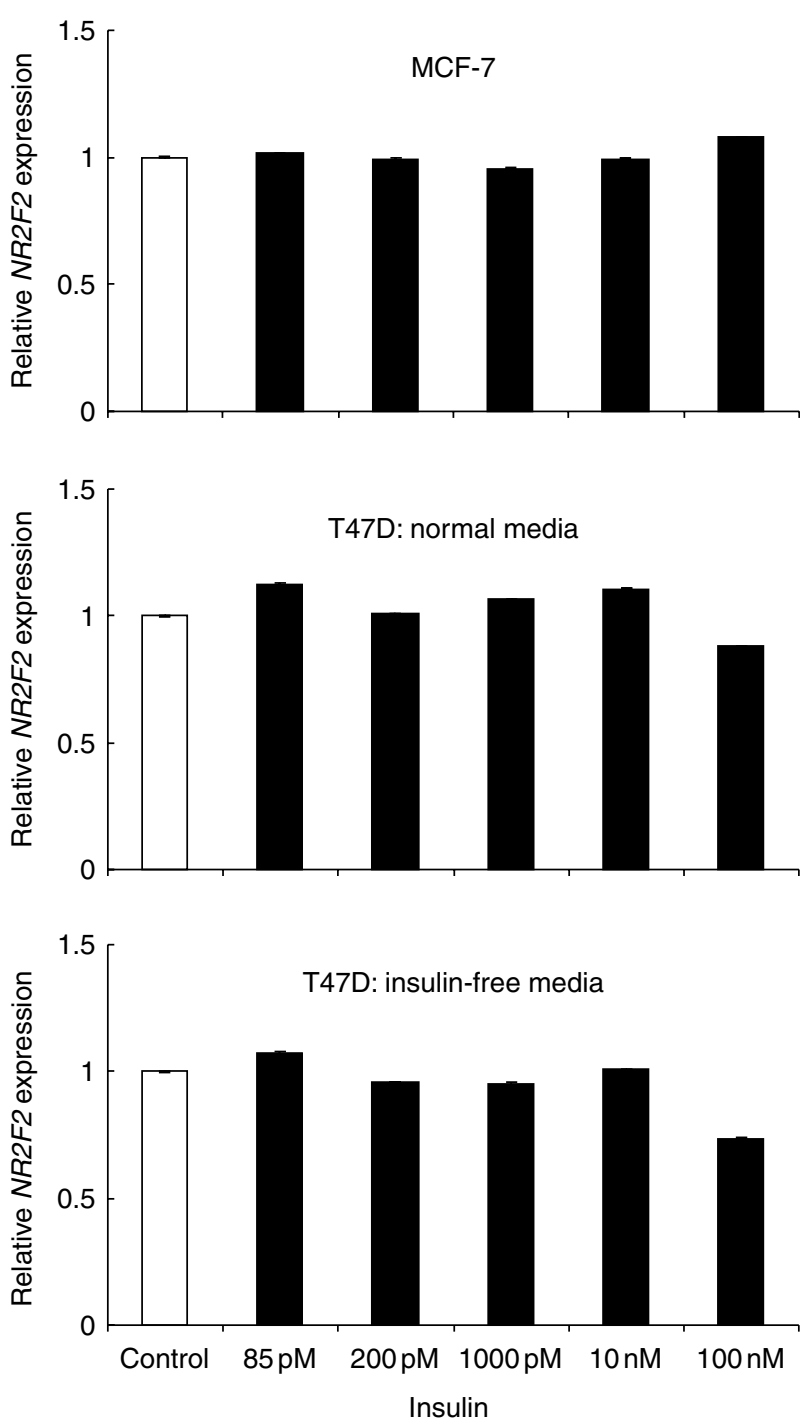

Figure 4 Insulin treatment does not affect COUP-TFII expression in human breast cancer cells. MCF-7 and T47D human breast cancer cells were grown as described in Litchfield et al. (2012). As T47D growth media contains $6 \mathrm{mg} / \mathrm{ml}$ insulin, T47D cells were grown either in normal media (with insulin) or in insulin-free media to determine whether this affected outcome. Before treatment with insulin, all cells were 'starved' in low glucose media (5 mM glucose) for $24 \mathrm{~h}$ (Perilhou et al. 2008a,b). Cells were treated for $6 \mathrm{~h}$ with the indicated concentrations of insulin. Quantitative RT-PCR was performed to measure NR2F2

expression relative to GAPDH as a reference gene, as described in Litchfield et al. (2012). Insulin treatment had no statistically significant effect on COUP-TFII expression in these cell lines.

Bullinger et al. 2010, Bell et al. 2011, Enjuanes et al. 2011, Vincent et al. 2011). NR2F2 gene hypermethylation was associated with a concordant reduction in mRNA expression in mantle cell lymphoma, pancreatic cancer, and tamoxifen-resistant breast cancer cells (Fan et al. 2006, Enjuanes et al. 2011, Vincent $e$ t al. 2011). Whether this indicates a general trend of reduced COUP-TFII expression due to epigenetic modification across cancer types remains to be seen. Contrary to these reports, high levels of COUP-TFII mRNA expression were found in all cell lines in the NCI60 panel of human cancer cell lines (Holbeck et al. 2010).

\section{Regulation by other transcription factors}

COUP-TFII and Ets-1 have overlapping expression patterns in mesenchymal cells of the mouse gut, spleen, lungs, and other tissues (Petit et al. 2004). Members of the ETS family (Ets-1, Ets-2, ETV, PEA3, Spi-1, and ERM) increased murine COUP-TFII-promoter activity in HeLa cells. Steroid receptor coactivators SRC-1/ NCOA1, TIF2/SRC-2/NCOA2, and RAC3/SRC-3/ NCOA3 enhanced the activation of the COUP-TFII promoter (Petit et al. 2004). In agreement with these data, SRC-3 and RAR $\alpha$ increased COUP-TFII-promoter activity in HepG2 human hepatocellular carcinoma cells with atRA treatment. Reciprocally, siRNA knockdown of SRC-3 repressed COUP-TFII expression (Ma et al. 2011). We observed that the protein expression (by immunohistochemical staining) of AIB1/SRC-3/ NCOA3, PEA3, and SRC-1/NCOA1 was correlated with COUP-TFII in breast cancer patient samples (Litchfield et al. 2012).

\section{Regulation by altered kinase activity and other signaling pathways}

Several factors were reported to alter COUP-TFII expression in pathogenic states. More et al. reported that expression of COUP-TFII, but not COUP-TFI, is stimulated by activation of the MAPK pathway. Breast cancer cell lines with increased MAPK activity, i.e. SKBR3, had a concomitant increase in COUP-TFII expression (More et al. 2003). In contrast to the idea that MAPK activation increases COUP-TFII expression, MAPK has also been shown to phosphorylate and inactivate protein phosphatase 2A (PP2A), leading to a suppression of COUP-TFII expression in human peripheral blood CD34+ cells (Aerbajinai et al. 2009). Inactivation of PP2A also inhibits sonic hedgehoginduced COUP-TFII expression in P19 cells (Krishnan et al. 1997). PP2A is inhibited by the FOXO transcription factors, including FOXO1 (Ni et al. 2007). COUPTFII expression is induced by FOXO1 in pancreatic $\beta$ cells and hepatocytes (Perilhou et al. 2008a), highlighting the highly cell type-specific nature of these pathways. MAPK activity may lead to increased COUPTFII expression in certain conditions, while it may alternatively repress COUP-TFII in others. Taken together, these data suggest a possible feedback loop in certain cell types (Fig. 3). 
In addition to MAPK activation, Notch signaling is also dysregulated in many types of cancer. Increased Notch signaling has been implicated in carcinogenesis and metastasis and is also involved in regulation of endothelial cell proliferation and angiogenesis (Garcia \& Kandel 2012, Gu et al. 2012). In breast cancer, Notch and its ligand Jagged1 upregulate the expression of Slug, a transcriptional repressor of E-cadherin important in metastatic progression (Leong et al. 2007). Notch signaling has also been implicated in the amplification of HER2 and survival of tumor initiating cells (Magnifico et al. 2009) and cancer stem cells (Harrison et al. 2010, Pannuti et al. 2010, Gu et al. 2012). Activation of the Notch pathway confers cancer-like properties and apoptosis resistance to normal breast epithelial cells (Stylianou et al. 2006). Regulation of COUP-TFII by Notch signaling has been reported in endothelial cells of both arterial and venous origin and in mouse studies (You et al. 2005, Kang et al. 2010, Srinivasan et al. 2010). Notch can suppress COUP-TFII and Prosperorelated homeobox domain 1 (Prox1), leading to an arterial rather than lymphatic phenotype in endothelial cells (Kang et al. 2010, Srinivasan et al. 2010, Francois et al. 2011). COUP-TFII, in turn, can also suppress Notch signaling to result in vein rather than artery formation (You et al. 2005). Transforming growth factor $\beta 1$ (TGF $\beta 1$ ) suppresses COUP-TFII expression in keratinocytes and fibroblasts leading to induction of collagen type VII (COL7A1) expression (Calonge et al. 2004) and in vascular progenitor cells to negatively regulate lymph vasculogenesis (Vittet et al. 2012). Whether COUP-TFII is regulated via Notch and TGF $\beta 1$ signaling has not yet been explored in cancer.

Amplification of Wnt/ $\beta$-catenin signaling has been widely reported in cancer (Incassati et al. 2010). In normal tissues, $\beta$-catenin signaling is controlled through signals leading to its phosphorylation by a multiprotein destruction complex and subsequent degradation. In breast and other cancers, increased expression of Wnt ligands leads to maintenance of $\beta$-catenin activation by preventing its degradation (Incassati et al. 2010). $\beta$-Catenin signaling has many outcomes, such as normal mammary morphogenesis and ductal maturation; however, sustained activation, through a variety of mechanisms, leads to carcinogenesis (Incassati et al. 2010). ChIP assays demonstrated that $\beta$-catenin/TCF7L2 (T-cell factor 7-like 2 or transcription factor 7-like 2) binds the promoter of COUP-TFII to activate expression, resulting in suppression of adipocyte differentiation (Okamura et al. 2009). COUP-TFII is expressed in mouse liver and pancreatic $\beta$-cells and plays roles in the maintenance of glucose homeostasis and insulin sensitivity (Bardoux et al. 2005, Perilhou et al. 2008a). Boutant et al. (2012) also reported that $\beta$-catenin/TCF7L2 induces COUP-TFII expression in the pancreas and that COUP-TFII expression was necessary for normal $\beta$-cell function and glucose tolerance in mice. The influence of $\beta$-catenin signaling on COUP-TFII expression in cancer has yet to be examined.

\section{Role of COUP-TFII in cancer}

\section{Angiogenesis}

Many studies of COUP-TFII involve its regulation of the angiogenesis pathway. Under normal conditions, angiogenesis is not active after the time of vasculature development during embryogenesis. However, upon progression of a tumor's growth, activation of angiogenesis leads to the formation of new blood vessels to support the tumor (Hanahan \& Weinberg 2011). COUP-TFII is necessary during normal development for angiogenesis and lymphangiogenesis, as evidenced by the impaired vessel formation and embryonic lethality in COUP-TFII knockout mice (Pereira et al. 1999, Lin et al. 2010). The expression of many proangiogenic factors is modulated by COUP-TFII, including members of the vascular endothelial growth factor (VEGF) family and their receptors. VEGF induces angiogenesis and lymphangiogenesis by activating tyrosine kinase receptors and upregulates endothelial cell proliferation and migration (Hoeben et al. 2004). In a model of pancreatic islet tumorigenesis, ablation of COUP-TFII increased VEGFR1 expression, impairing VEGFR2 signaling and reducing angiogenesis (Qin et al. 2010b). Metastasis to regional lymph nodes was reduced as a result, implying that COUP-TFII may have a pro-angiogenic, pro-metastatic role in pancreatic cancer (Qin et al. 2010b). Similarly, ablation of COUP-TFII decreased tumorigenesis in B16-F10 melanoma and Lewis lung carcinoma mouse xenografts and reduced tumorigenesis and metastasis in a spontaneous mouse mammary tumor model. These effects were attributed to a decrease in blood vessel density in COUP-TFII-deficient mice (Qin et al. 2010a).

In addition to regulating VEGFR expression, COUP-TFII can also affect angiogenesis via regulation of Ang-1, through binding to an Sp1 site in the promoter region. The induction of Ang-1 is partially responsible for the effects of COUP-TFII, as overexpression of Ang- 1 allowed for recovery of angiogenesis in COUP-TFII-deficient mice (Qin et al. 2010a).

Lymphangiogenesis can also contribute to metastasis by allowing the spread of tumor cells to lymph nodes (Achen et al. 2005, Tobler \& Detmar 2006). COUP-TFII regulates tumor lymphangiogenesis via inducing expression of VEGF-C and neuropilin-2, a coreceptor for VEGF-C (Nagasaki et al. 2009, Lin et al. 2010). In a murine model of pancreatic islet tumorigenesis, COUPTFII deletion resulted in impaired lymphangiogenesis 
and reduced metastasis (Qin et al. 2010b). Concordant with a role for COUP-TFII in lymphangiogenesis, Kang et al. (2010) reported that Notch suppresses COUP-TFII expression, along with Prox1, in human primary dermal lymphatic endothelial cells to signal for arterial rather than lymphatic differentiation. Suppression of COUP-TFII resulted in an increase in VEGF signaling by activating expression of VEGFR2, a VEGF receptor whose signaling can feed back to increase activation of Notch signaling (Kang et al. 2010).

COUP-TFII induction by 9cRA was also shown to promote network formation but not cell fusion in SKBR3 breast cancer cells, suggesting a role in the endothelial transdifferentiation pathway as a necessary part of vascular formation (Prahalad et al. 2010). Taken together, these data indicate that COUP-TFII may regulate angiogenesis and lymphangiogenesis, primarily through modulation of VEGF and its receptor in a cell context-dependent manner.

\section{Invasion and metastasis}

In addition to stimulation of angiogenesis, COUP-TFII may have other distinct roles in regulation of tumor growth and metastasis. Transfection with COUP-TFII in A549, H520, and H441 lung cancer cells and MDAMB-231 breast cancer cells was reported to increase migration and invasion (Navab et al. 2004). Navab et al. (2004) found that COUP-TFII upregulated the expression of extracellular matrix-degrading proteinases matrix metalloproteinase 2 (MMP2) and urokinasetype plasminogen activator (uPA). MMP2 and uPA are known to play critical roles in cancer, particularly in angiogenesis and metastasis (Annecke et al. 2008). High levels of uPA are predictive of not only recurrence but also a favorable response to adjuvant chemotherapy in breast cancer patients (Harbeck et al. 2004). Interestingly, it has also been reported that uPA expression is dependent on Notch signaling in MDA-MB-231, MDA-MB-468, and HCC1143 breast cancer cells (Shimizu et al. 2011). COUP-TFII and MMP2 expression were also positively correlated in a breast tumor microarray (Litchfield et al. 2012), further indicating a potential relationship between COUP-TFII and extracellular matrix degradation. By contrast, COUP-TFII decreased cell motility when transfected into LY2 tamoxifen-resistant breast cancer cells, while having no significant effect on invasion (Riggs et al. 2006).

\section{Estrogen receptor and clinical outcome}

Nagasaki et al. (2009) demonstrated that COUP-TFII expression was correlated with $\mathrm{ER} \alpha$ status and indices of poor clinical outcome (clinical stage, lymph node status, and histological grade) in human breast tumor samples, indicating that COUP-TFII may play a role in cancer progression. We also found that COUP-TFII and $\mathrm{ER} \alpha$ expression were correlated in a human breast tissue/tumor microarray, but instead noted an inverse relationship between COUP-TFII expression and tumor, node, and metastasis (TNM) classification (Litchfield et al. 2012). Similar findings were observed at the mRNA level by examining breast tumor mRNA transcriptomes in Oncomine (Litchfield et al. 2012). COUP-TFII expression was significantly higher in $\mathrm{ER} \alpha+$ breast cancer samples and significantly lower in metastatic samples (Litchfield et al. 2012). These findings indicate a function for COUP-TFII in inhibiting tumor progression. A positive correlation with $\mathrm{ER} \alpha$ is consistent with a previous report that siRNA knockdown of ER $\alpha$ in MCF-7 breast cancer cells decreased COUP-TFII expression and treatment with estradiol increased the expression of COUP-TFII (Riggs et al. 2006). ER $\alpha$ is a positive prognostic factor in breast tumors and is the target of endocrine-targeted cancer therapeutics such as the selective ER modulators (SERMs) tamoxifen and raloxifene (Jordan 2009). COUP-TFII, but not COUP-TFI, is reduced in tamoxifen-resistant human breast cancer cells, and re-expression of COUP-TFII can restore tamoxifen sensitivity (Riggs et al. 2006). As $\mathrm{ER} \alpha$ expression is important in keeping breast cancer cells responsive to treatment, the correlation of COUP-TFII and ER $\alpha$ further demonstrates a beneficial role for COUP-TFII, highlighting its potential importance in maintaining differentiation and endocrine sensitivity.

In contrast to a role for COUP-TFII in maintaining antiestrogen sensitivity, Holbeck et al. (2010) reported that cancer cells in the NCI60 panel expressing low levels of COUP-TFII showed higher sensitivity to microtubule-targeting drugs vinblastine, colchicines, and taxol. These data demonstrate that both cell typespecific as well as drug-specific mechanisms may determine the role of COUP-TFII in influencing treatment response.

\section{Steroidogenesis}

COUP-TFII expression was reported to be high in aldosteroma, with an inverse correlation with adrenal steroidogenesis (Suzuki et al. 2000b). These data also indicated an inverse correlation between COUP-TFII expression and CYP17A1 expression, with COUP-TFII inhibiting CYP17A1 in aldosteroma (Suzuki et al. 2000b). COUP-TFII competed with SF-1 for binding to overlapping sites within the promoters of the Cyp17a1 (Bakke \& Lund 1995, van den Driesche et al. 2012), Cyp11a1, and Star (STARD1) genes in rat Leydig cells and to suppress testosterone production (van den Driesche et al. 2012). Both COUP-TFI and COUP-TFII repressed angiotensin II-stimulated STARD1 (STAR) in 
bovine adrenal glomerulosa cells in primary culture (Buholzer et al. 2005). COUP-TFII also competed with SF-1 for the human aromatase $\mathrm{P} 450$ promoter II in primary endometriotic stromal cells and suppressed aromatase expression (Zeitoun et al. 1999). Overexpression of SF-1 in primary endometriotic stromal cells outcompeted the normal protective effect of COUP-TF (whether COUP-TFI or COUP-TFII involved was unclear as both were equally expressed at the mRNA level), resulting in high local aromatase expression in endometriosis (Zeitoun et al. 1999). COUP-TFII was reported to bind the $\mathrm{S} 1$ silencer region of the human aromatase gene and suppress transcription in MCF-7 cells (Yang et al. 2002). Indeed, the decreases in COUP-TFI, EAR $\gamma$, EAR-2, Snail, and Slug in breast cancer were suggested to increase aromatase expression (Chen et al. 2005). Thus, the downregulation of COUP-TFII expression that we observed in endocrine-resistant breast cancer cells (Riggs et al. 2006) would be expected to increase aromatase and thus increase local estrogen production. However, whether increased COUP-TFII suppresses local androgen or estrogen biosynthesis in breast tissue is unknown. Local conversion of adrenal androgens to estrogens by aromatase is the target of aromatase inhibitor (AI) therapy for postmenopausal women. However, there are androgen metabolites (e.g. 3 $\beta$-adiol) that bypass aromatase, which activate $\mathrm{ER} \alpha$ and $\mathrm{ER} \beta$ and may play a role in AI resistance (Sikora et al. 2009, 2012). Overall, the literature supports a negative role for COUP-TFII in regulating steroid hormone synthesis and further studies addressing COUP-TFII regulation of aromatase gene expression in local estrogen production in breast (Bulun et al. 2012) and lung (Marquez-Garban et al. 2009) adenocarcinomas would be of merit.

\section{Conclusions}

The studies reviewed here indicate that COUP-TFII is regulated and is functionally active to regulate target gene transcription in a cell type-dependent manner. There is evidence that COUP-TFII may perform both pro- and anti-tumorigenic roles. COUP-TFII has been reported to increase angiogenesis and lymphangiogenesis, both increase and decrease tumor metastasis, lead to favorable and unfavorable therapeutic outcome in cancer therapy, and suppress steroidogenesis. Qin $e t$ al. (2010a) reported that COUP-TFII was not expressed in tumor cells, but rather was found in high concentrations in the surrounding blood vessels that support tumor growth and spread. This indicates a crucial point of consideration about the nature of COUP-TFII in cancer formation and progression: the function of COUP-TFII within cancer cells vs in the surrounding tumor microenvironment and other cell types. Tissue type is clearly an important determinant in deciphering the oncogenic or tumor-suppressive nature of COUP-TFII. Many studies published to date involve the regulation and role of COUP-TFII during development and in noncancerous disease states. The full applicability of these studies to our knowledge of the role of COUPTFII in carcinogenesis and cancer progression remains to be seen. Future studies are necessary to elucidate the complex nature of this vital NR.

\section{Declaration of interest}

The authors declare that there is no conflict of interest that could be perceived as prejudicing the impartiality of the review reported.

\section{Funding}

This work was supported by a grant from Susan G Komen for the Cure KG080365 to C M K. L M L is supported by a fellowship from NIEHS T32 ES011564.

\section{References}

Achen MG, McColl BK \& Stacker SA 2005 Focus on lymphangiogenesis in tumor metastasis. Cancer Cell 7 121-127. (doi:10.1016/ j.ccr.2005.01.017)

Aerbajinai W, Zhu J, Kumkhaek C, Chin K \& Rodgers GP 2009 SCF induces gamma-globin gene expression by regulating downstream transcription factor COUP-TFII. Blood 114 187-194. (doi:10.1182/ blood-2008-07-170712)

Ahmad N \& Kumar R 2011 Steroid hormone receptors in cancer development: a target for cancer therapeutics. Cancer Letters 300 1-9. (doi:10.1016/j.canlet.2010.09.008)

Annecke K, Schmitt M, Euler U, Zerm M, Paepke D, Paepke S, von Minckwitz G, Thomssen C \& Harbeck N 2008 uPA and PAI-1 in breast cancer: review of their clinical utility and current validation in the prospective NNBC-3 trial. Advances in Clinical Chemistry 45 31-45. (doi:10.1016/S0065-2423(07)00002-9)

Bailey PJ, Dowhan DH, Franke K, Burke LJ, Downes M \& Muscat GE 1997 Transcriptional repression by COUP-TF II is dependent on the C-terminal domain and involves the N-CoR variant, RIP13deltal. Journal of Steroid Biochemistry and Molecular Biology 63 165-174. (doi:10.1016/S0960-0760(97)00079-4)

Bakke M \& Lund J 1995 Mutually exclusive interactions of two nuclear orphan receptors determine activity of a cyclic adenosine $3^{\prime}, 5^{\prime}$ monophosphate-responsive sequence in the bovine CYP17 gene. Molecular Endocrinology 9 327-339. (doi:10.1210/me.9.3.327)

Bardoux P, Zhang P, Flamez D, Perilhou A, Lavin TA, Tanti JF, Hellemans K, Gomas E, Godard C, Andreelli F et al. 2005 Essential role of chicken ovalbumin upstream promoter-transcription factor II in insulin secretion and insulin sensitivity revealed by conditional gene knockout. Diabetes 54 1357-1363. (doi:10.2337/ diabetes.54.5.1357)

Bell A, Bell D, Weber RS \& El-Naggar AK 2011 CpG island methylation profiling in human salivary gland adenoid cystic carcinoma. Cancer 117 2898-2909. (doi:10.1002/cncr.25818)

Ben-Shushan E, Sharir H, Pikarsky E \& Bergman Y 1995 A dynamic balance between ARP-1/COUP-TFII, EAR-3/COUP-TFI, and retinoic acid receptor:retinoid $\mathrm{X}$ receptor heterodimers regulates Oct-3/4 expression in embryonal carcinoma cells. Molecular and Cellular Biology 15 1034-1048. 
Boutant M, Ramos OH, Tourrel-Cuzin C, Movassat J, Ilias A, Vallois D, Planchais J, Pegorier JP, Schuit F, Petit PX et al. 2012 COUP-TFII controls mouse pancreatic $\beta$-cell mass through GLP-1- $\beta$-catenin signaling pathways. PLoS ONE 7 e30847. (doi:10.1371/journal. pone.0030847)

Buholzer CF, Arrighi JF, Abraham S, Piguet V, Capponi AM \& Casal AJ 2005 Chicken ovalbumin upstream promoter-transcription factor is a negative regulator of steroidogenesis in bovine adrenal glomerulosa cells. Molecular Endocrinology 19 65-75. (doi:10.1210/ me.2004-0061)

Bullinger L, Ehrich M, Dohner K, Schlenk RF, Dohner H, Nelson MR \& van den Boom D 2010 Quantitative DNA methylation predicts survival in adult acute myeloid leukemia. Blood 115 636-642. (doi:10.1182/blood-2009-03-211003)

Bulun SE, Chen D, Moy I, Brooks DC \& Zhao H 2012 Aromatase, breast cancer and obesity: a complex interaction. Trends in Endocrinology and Metabolism 23 83-89. (doi:10.1016/ j.tem.2011.10.003)

Calonge MJ, Seoane J \& Massague J 2004 Opposite Smad and chicken ovalbumin upstream promoter transcription factor inputs in the regulation of the collagen VII gene promoter by transforming growth factor- $\beta$. Journal of Biological Chemistry 279 23759-23765. (doi:10.1074/jbc.M402178200)

Chen S, Ye J, Kijima I, Kinoshita Y \& Zhou D 2005 Positive and negative transcriptional regulation of aromatase expression in human breast cancer tissue. Journal of Steroid Biochemistry and Molecular Biology 95 17-23. (doi:10.1016/j.jsbmb.2005.04.002)

Chu K \& Zingg HH 1997 The nuclear orphan receptors COUP-TFII and Ear-2 act as silencers of the human oxytocin gene promoter. Journal of Molecular Endocrinology 19 163-172. (doi:10.1677/jme.0. 0190163)

Cooney AJ, Leng X, Tsai SY, O’Malley BW \& Tsai MJ 1993 Multiple mechanisms of chicken ovalbumin upstream promoter transcription factor-dependent repression of transactivation by the vitamin $\mathrm{D}$, thyroid hormone, and retinoic acid receptors. Journal of Biological Chemistry 268 4152-4160.

Deaton AM \& Bird A 2011 CpG islands and the regulation of transcription. Genes and Development 25 1010-1022. (doi:10.1101/ $\operatorname{gad} .2037511)$

De Martino MU, Alesci S, Chrousos GP \& Kino T 2004a Interaction of the glucocorticoid receptor and the chicken ovalbumin upstream promoter-transcription factor II (COUP-TFII): implications for the actions of glucocorticoids on glucose, lipoprotein, and xenobiotic metabolism. PNAS 1024 72-85. (doi:10.1196/annals.1321.006)

De Martino MU, Bhattachryya N, Alesci S, Ichijo T, Chrousos GP \& Kino T $2004 b$ The glucocorticoid receptor and the orphan nuclear receptor chicken ovalbumin upstream promoter-transcription factor II interact with and mutually affect each other's transcriptional activities: implications for intermediary metabolism. Molecular Endocrinology 18 820-833. (doi:10.1210/me.2003-0341)

van den Driesche S, Walker M, McKinnell C, Scott HM, Eddie SL, Mitchell RT, Seckl JR, Drake AJ, Smith LB, Anderson RA et al. 2012 Proposed role for COUP-TFII in regulating fetal leydig cell steroidogenesis, perturbation of which leads to masculinization disorders in rodents. PLoS ONE 7 e37064. (doi:10.1371/journal. pone.0037064)

Enjuanes A, Fernandez V, Hernandez L, Navarro A, Bea S, Pinyol M, Lopez-Guillermo A, Rosenwald A, Ott G, Campo E et al. 2011 Identification of methylated genes associated with aggressive clinicopathological features in mantle cell lymphoma. PLoS ONE 6 e19736. (doi:10.1371/journal.pone.0019736)

Eubank DW, Duplus E, Williams SC, Forest C \& Beale EG 2001 Peroxisome proliferator-activated receptor $\gamma$ and chicken ovalbumin upstream promoter transcription factor II negatively regulate the phosphoenolpyruvate carboxykinase promoter via a common element. Journal of Biological Chemistry 276 30561-30569. (doi:10.1074/jbc.M103019200)
Fan M, Yan PS, Hartman-Frey C, Chen L, Paik H, Oyer SL, Salisbury JD, Cheng AS, Li L, Abbosh PH et al. 2006 Diverse gene expression and DNA methylation profiles correlate with differential adaptation of breast cancer cells to the antiestrogens tamoxifen and fulvestrant. Cancer Research 66 11954-11966. (doi:10.1158/ 0008-5472.CAN-06-1666)

Ferguson R, Novosyadlyy R, Fierz Y, Alikhani N, Sun H, Yakar S \& LeRoith D 2012 Hyperinsulinemia enhances c-Myc-mediated mammary tumor development and advances metastatic progression to the lung in a mouse model of type 2 diabetes. Breast Cancer Research 14 R8. (doi:10.1186/bcr3089)

Fernandez-Rachubinski F \& Fliegel L 2001 COUP-TFI and COUP-TFII regulate expression of the NHE through a nuclear hormone responsive element with enhancer activity. European Journal of Biochemistry 268 620-634. (doi:10.1046/j.1432-1327.2001. 01915.x)

Francois M, Harvey NL \& Hogan BM 2011 The transcriptional control of lymphatic vascular development. Physiology 26 146-155. (doi:10.1152/physiol.00053.2010)

Garcia A \& Kandel JJ 2012 Notch: a key regulator of tumor angiogenesis and metastasis. Histology and Histopathology 27 151-156.

Gu JW, Rizzo P, Pannuti A, Golde T, Osborne B \& Miele L 2012 Notch signals in the endothelium and cancer "stem-like" cells: opportunities for cancer therapy. Vascular Cell 4 7. (doi:10.1186/ 2045-824X-4-7)

Gunter MJ, Hoover DR, Yu H, Wassertheil-Smoller S, Rohan TE, Manson JE, Li J, Ho GY, Xue X, Anderson GL et al. 2009 Insulin, insulin-like growth factor-I, and risk of breast cancer in postmenopausal women. Journal of the National Cancer Institute 101 48-60. (doi:10.1093/jnci/djn415)

Hammond GL 2011 Diverse roles for sex hormone-binding globulin in reproduction. Biology of Reproduction 85 431-441. (doi:10.1095/ biolreprod.111.092593)

Hanahan D \& Weinberg RA 2011 Hallmarks of cancer: the next generation. Cell 144 646-674. (doi:10.1016/j.cell.2011.02.013)

Harbeck N, Kates RE, Schmitt M, Gauger K, Kiechle M, Janicke F, Thomassen C, Look MP \& Foekens JA 2004 Urokinase-type plasminogen activator and its inhibitor type 1 predict disease outcome and therapy response in primary breast cancer. Clinical Breast Cancer 5 348-352. (doi:10.3816/CBC.2004.n.040)

Harrison H, Farnie G, Howell SJ, Rock RE, Stylianou S, Brennan KR, Bundred NJ \& Clarke RB 2010 Regulation of breast cancer stem cell activity by signaling through the Notch 4 receptor. Cancer Research 70 709-718. (doi:10.1158/0008-5472.CAN-09-1681)

Hoeben A, Landuyt B, Highley MS, Wildiers H, Van Oosterom AT \& De Bruijn EA 2004 Vascular endothelial growth factor and angiogenesis. Pharmacological Reviews 56 549-580. (doi:10.1124/ pr.56.4.3)

Holbeck S, Chang J, Best AM, Bookout AL, Mangelsdorf DJ \& Martinez ED 2010 Expression profiling of nuclear receptors in the NCI60 cancer cell panel reveals receptor-drug and receptor-gene interactions. Molecular Endocrinology 24 1287-1296. (doi:10.1210/ me.2010-0040)

Huggins GS, Bacani CJ, Boltax J, Aikawa R \& Leiden JM 2001 Friend of GATA 2 physically interacts with chicken ovalbumin upstream promoter-TF2 (COUP-TF2) and COUP-TF3 and represses COUPTF2-dependent activation of the atrial natriuretic factor promoter. Journal of Biological Chemistry 276 28029-28036. (doi:10.1074/ jbc.M103577200)

Incassati A, Chandramouli A, Eelkema R \& Cowin P 2010 Key signaling nodes in mammary gland development and cancer: $\beta$-catenin. Breast Cancer Research 12 213. (doi:10.1186/bcr2723)

Irizarry RA, Ladd-Acosta C, Wen B, Wu Z, Montano C, Onyango P, Cui H, Gabo K, Rongione M, Webster M et al. 2009 The human colon cancer methylome shows similar hypo- and hypermethylation at conserved tissue-specific CpG island shores. Nature Genetics 41 178-186. (doi:10.1038/ng.298) 
Janne M \& Hammond GL 1998 Hepatocyte nuclear factor-4 controls transcription from a TATA-less human sex hormone-binding globulin gene promoter. Journal of Biological Chemistry 273 34105-34114. (doi:10.1074/jbc.273.51.34105)

Jiang G, Nepomuceno L, Hopkins K \& Sladek FM 1995 Exclusive homodimerization of the orphan receptor hepatocyte nuclear factor 4 defines a new subclass of nuclear receptors. Molecular and Cellular Biology 15 5131-5143.

Jordan VC 2009 A century of deciphering the control mechanisms of sex steroid action in breast and prostate cancer: the origins of targeted therapy and chemoprevention. Cancer Research 69 1243-1254. (doi:10.1158/0008-5472.CAN-09-0029)

Kang J, Yoo J, Lee S, Tang W, Aguilar B, Ramu S, Choi I, Otu HH, Shin JW, Dotto GP et al. 2010 An exquisite cross-control mechanism among endothelial cell fate regulators directs the plasticity and heterogeneity of lymphatic endothelial cells. Blood 116 140-150. (doi:10.1182/blood-2009-11-252270)

Kliewer SA, Umesono K, Heyman RA, Mangelsdorf DJ, Dyck JA \& Evans RM 1992 Retinoid X receptor-COUP-TF interactions modulate retinoic acid signaling. PNAS 89 1448-1452. (doi:10.1073/pnas.89.4.1448)

Klinge CM, Silver BF, Driscoll MD, Sathya G, Bambara RA \& Hilf R 1997 Chicken ovalbumin upstream promoter-transcription factor interacts with estrogen receptor, binds to estrogen response elements and half-sites, and inhibits estrogen-induced gene expression. Journal of Biological Chemistry 272 31465-31474. (doi:10.1074/jbc.272.50.31465)

Krishnan V, Pereira FA, Qiu Y, Chen CH, Beachy PA, Tsai SY \& Tsai MJ 1997 Mediation of Sonic hedgehog-induced expression of COUP-TFII by a protein phosphatase. Science 278 1947-1950. (doi:10.1126/science.278.5345.1947)

Kruse SW, Suino-Powell K, Zhou XE, Kretschman JE, Reynolds R, Vonrhein C, Xu Y, Wang L, Tsai SY, Tsai MJ et al. 2008 Identification of COUP-TFII orphan nuclear receptor as a retinoic acid-activated receptor. PLoS Biology 6 e227. (doi:10.1371/journal.pbio.0060227)

Ktistaki E \& Talianidis I 1997 Chicken ovalbumin upstream promoter transcription factors act as auxiliary cofactors for hepatocyte nuclear factor 4 and enhance hepatic gene expression. Molecular and Cellular Biology 17 2790-2797.

Kurihara I, Shibata H, Kobayashi S, Suda N, Ikeda Y, Yokota K, Murai A, Saito I, Rainey WE \& Saruta T 2005 Ubc9 and protein inhibitor of activated STAT 1 activate chicken ovalbumin upstream promotertranscription factor I-mediated human CYP11B2 gene transcription. Journal of Biological Chemistry 280 6721-6730. (doi:10.1074/jbc. M411820200)

Kyrmizi I, Hatzis P, Katrakili N, Tronche F, Gonzalez FJ \& Talianidis I 2006 Plasticity and expanding complexity of the hepatic transcription factor network during liver development. Genes and Development 20 2293-2305. (doi:10.1101/gad.390906)

Lavrentiadou SN, Hadzopoulou-Cladaras M, Kardassis D \& Zannis VI 1999 Binding specificity and modulation of the human ApoCIII promoter activity by heterodimers of ligand-dependent nuclear receptors. Biochemistry 38 964-975. (doi:10.1021/bi981068i)

Lee MO, Liu Y \& Zhang XK 1995 A retinoic acid response element that overlaps an estrogen response element mediates multihormonal sensitivity in transcriptional activation of the lactoferrin gene. Molecular and Cellular Biology 15 4194-4207.

Lee CT, Li L, Takamoto N, Martin JF, Demayo FJ, Tsai MJ \& Tsai SY 2004 The nuclear orphan receptor COUP-TFII is required for limb and skeletal muscle development. Molecular and Cellular Biology 24 10835-10843. (doi:10.1128/MCB.24.24.10835-10843.2004)

Lee KN, Jang WG, Kim EJ, Oh SH, Son HJ, Kim SH, Franceschi R, Zhang XK, Lee SE \& Koh JT 2012 Orphan nuclear receptor COUPTFII negatively regulates BMP2-induced osteoblast differentiation through suppressing Runx2 activity. Journal of Biological Chemistry 287 18888-18899.

Leong KG, Niessen K, Kulic I, Raouf A, Eaves C, Pollet I \& Karsan A 2007 Jagged1-mediated Notch activation induces epithelial-to-mesenchymal transition through Slug-induced repression of E-cadherin. Journal of Experimental Medicine 204 2935-2948. (doi:10.1084/jem.20071082)

Li X, Misik AJ, Rieder CV, Solaro RJ, Lowen A \& Fliegel L 2002 Thyroid hormone receptor $\alpha 1$ regulates expression of the $\mathrm{Na}+/ \mathrm{H}+$ exchanger (NHE1). Journal of Biological Chemistry 277 28656-28662. (doi:10.1074/jbc.M203221200)

Liberati C, Cera MR, Secco P, Santoro C, Mantovani R, Ottolenghi S \& Ronchi A 2001 Cooperation and competition between the binding of COUP-TFII and NF-Y on human epsilon- and gamma-globin gene promoters. Journal of Biological Chemistry 276 41700-41709. (doi:10.1074/jbc.M102987200)

Lin B, Chen GQ, Xiao D, Kolluri SK, Cao X, Su H \& Zhang XK 2000 Orphan receptor COUP-TF is required for induction of retinoic acid receptor $\beta$, growth inhibition, and apoptosis by retinoic acid in cancer cells. Molecular and Cellular Biology 20 957-970. (doi:10.1128/ MCB.20.3.957-970.2000)

Lin F, Kolluri SK, Chen GQ \& Zhang XK 2002 Regulation of retinoic acid-induced inhibition of AP-1 activity by orphan receptor chicken ovalbumin upstream promoter-transcription factor. Journal of Biological Chemistry 277 21414-21422. (doi:10.1074/jbc.M201885200)

Lin FJ, Chen X, Qin J, Hong YK, Tsai MJ \& Tsai SY 2010 Direct transcriptional regulation of neuropilin-2 by COUP-TFII modulates multiple steps in murine lymphatic vessel development. Journal of Clinical Investigation 120 1694-1707. (doi:10.1172/JCI40101)

Lin FJ, Qin J, Tang K, Tsai SY \& Tsai MJ 2011 Coup d'Etat: an orphan takes control. Endocrine Reviews 32 404-421.

Litchfield LM, Riggs KA, Hockenberry AM, Oliver LD, Barnhart KG, Cai J, Pierce WM Jr, Ivanova MM, Bates PJ, Appana SN et al. 2012 Identification and characterization of nucleolin as a COUP-TFII coactivator of retinoic acid receptor $\beta$ transcription in breast cancer cells. PLoS ONE 7 e38278. (doi:10.1371/journal.pone.0038278)

Lovat F, Valeri N \& Croce CM 2011 MicroRNAs in the pathogenesis of cancer. Seminars in Oncology 38 724-733. (doi:10.1053/j.seminoncol. 2011.08.006)

Ma X, Xu L, Wang S, Cui B, Li X, Xu J \& Ning G 2011 Deletion of steroid receptor coactivator-3 gene ameliorates hepatic steatosis. Journal of Hepatology 55 445-452. (doi:10.1016/j.jhep.2010.11.022)

Magnifico A, Albano L, Campaner S, Delia D, Castiglioni F, Gasparini P, Sozzi G, Fontanella E, Menard S \& Tagliabue E 2009 Tumor-initiating cells of HER2-positive carcinoma cell lines express the highest oncoprotein levels and are sensitive to trastuzumab. Clinical Cancer Research 15 2010-2021. (doi:10.1158/1078-0432.CCR-08-1327)

Marcus SL, Winrow CJ, Capone JP \& Rachubinski RA 1996 A p56(lck) ligand serves as a coactivator of an orphan nuclear hormone receptor. Journal of Biological Chemistry 271 27197-27200. (doi:10.1074/jbc.271.44.27197)

Marquez-Garban DC, Chen HW, Goodglick L, Fishbein MC \& Pietras RJ 2009 Targeting aromatase and estrogen signaling in human non-small cell lung cancer. Annals of the New York Academy of Sciences 1155 194-205. (doi:10.1111/j.1749-6632.2009.04116.x)

Mietus-Snyder M, Sladek FM, Ginsburg GS, Kuo CF, Ladias JA, Darnell JE Jr \& Karathanasis SK 1992 Antagonism between apolipoprotein AI regulatory protein 1, Ear3/COUP-TF, and hepatocyte nuclear factor 4 modulates apolipoprotein CIII gene expression in liver and intestinal cells. Molecular and Cellular Biology 12 1708-1718.

More E, Fellner T, Doppelmayr H, Hauser-Kronberger C, Dandachi N, Obrist P, Sandhofer F \& Paulweber B 2003 Activation of the MAP kinase pathway induces chicken ovalbumin upstream promotertranscription factor II (COUP-TFII) expression in human breast cancer cell lines. Journal of Endocrinology 176 83-94. (doi:10.1677/ joe.0.1760083)

Nagasaki S, Suzuki T, Miki Y, Akahira J, Shibata H, Ishida T, Ohuchi N \& Sasano H 2009 Chicken ovalbumin upstream promoter transcription factor II in human breast carcinoma: possible 
regulator of lymphangiogenesis via vascular endothelial growth factor-C expression. Cancer Science 100 639-645. (doi:10.1111/j. 1349-7006.2008.01078.x)

Nakshatri H \& Chambon P 1994 The directly repeated RG(G/T)TCA motifs of the rat and mouse cellular retinol-binding protein II genes are promiscuous binding sites for RAR, RXR, HNF-4, and ARP-1 homo- and heterodimers. Journal of Biological Chemistry 269 890-902.

Nakshatri H, Mendonca MS, Bhat-Nakshatri P, Patel NM, Goulet RJ Jr \& Cornetta K 2000 The orphan receptor COUP-TFII regulates $\mathrm{G} 2 / \mathrm{M}$ progression of breast cancer cells by modulating the expression/activity of p21 (WAF1/CIP1), cyclin D1, and cdk2. Biochemical and Biophysical Research Communications 270 1144-1153. (doi:10.1006/bbrc.2000.2562)

Navab R, Gonzalez-Santos JM, Johnston MR, Liu J, Brodt P, Tsao MS \& $\mathrm{Hu} \mathrm{J} 2004$ Expression of chicken ovalbumin upstream promotertranscription factor II enhances invasiveness of human lung carcinoma cells. Cancer Research 64 5097-5105. (doi:10.1158/00085472.CAN-03-1185)

Ni YG, Wang N, Cao DJ, Sachan N, Morris DJ, Gerard RD, Kuro OM, Rothermel BA \& Hill JA 2007 FoxO transcription factors activate Akt and attenuate insulin signaling in heart by inhibiting protein phosphatases. PNAS 104 20517-20522. (doi:10.1073/pnas.0610290104)

Ochoa A, Bovard-Houppermans S \& Zakin MM 1993 Human apolipoprotein A-IV gene expression is modulated by members of the nuclear hormone receptor superfamily. Biochimica et Biophysica Acta 1210 41-47. (doi:10.1016/0005-2760(93)90047-D)

Okamura M, Kudo H, Wakabayashi K, Tanaka T, Nonaka A, Uchida A, Tsutsumi S, Sakakibara I, Naito M, Osborne TF et al. 2009 COUPTFII acts downstream of Wnt/ $\beta$-catenin signal to silence PPAR $\gamma$ gene expression and repress adipogenesis. PNAS 106 5819-5824. (doi:10.1073/pnas.0901676106)

Pannuti A, Foreman K, Rizzo P, Osipo C, Golde T, Osborne B \& Miele L 2010 Targeting Notch to target cancer stem cells. Clinical Cancer Research 16 3141-3152. (doi:10.1158/1078-0432. CCR-09-2823)

Pereira FA, Qiu Y, Zhou G, Tsai MJ \& Tsai SY 1999 The orphan nuclear receptor COUP-TFII is required for angiogenesis and heart development. Genes and Development 13 1037-1049. (doi:10.1101/ gad.13.8.1037)

Perilhou A, Tourrel-Cuzin C, Kharroubi I, Henique C, Fauveau V, Kitamura T, Magnan C, Postic C, Prip-Buus C \& Vasseur-Cognet M $2008 a$ The transcription factor COUP-TFII is negatively regulated by insulin and glucose via Foxol- and ChREBP-controlled pathways. Molecular and Cellular Biology 28 6568-6579. (doi:10.1128/MCB. 02211-07)

Perilhou A, Tourrel-Cuzin C, Zhang P, Kharroubi I, Wang H, Fauveau V, Scott DK, Wollheim CB \& Vasseur-Cognet M 2008 $b$ The MODY1 gene for hepatocyte nuclear factor $4 \alpha$ and a feedback loop control COUP-TFII expression in pancreatic $\beta$ cells. Molecular and Cellular Biology 28 4588-4597. (doi:10.1128/MCB.01191-07)

Petit FG, Salas R, Tsai MJ \& Tsai SY 2004 The regulation of COUP-TFII gene expression by Ets-1 is enhanced by the steroid receptor co-activators. Mechanisms of Ageing and Development 125 719-732. (doi:10.1016/j.mad.2004.03.009)

Pineda Torra I, Jamshidi Y, Flavell DM, Fruchart JC \& Staels B 2002 Characterization of the human PPAR $\alpha$ promoter: identification of a functional nuclear receptor response element. Molecular Endocrinology 16 1013-1028. (doi:10.1210/me.16.5.1013)

Pipaon C, Tsai SY \& Tsai MJ 1999 COUP-TF upregulates NGFI-A gene expression through an Sp1 binding site. Molecular and Cellular Biology 19 2734-2745.

Power SC \& Cereghini S 1996 Positive regulation of the vHNF1 promoter by the orphan receptors COUP-TF1/Ear3 and COUP-TFII/Arp1. Molecular and Cellular Biology 16 778-791.

Prahalad P, Dakshanamurthy S, Ressom H \& Byers SW 2010 Retinoic acid mediates regulation of network formation by COUP-TFII and VE-cadherin expression by TGF $\beta$ receptor kinase in breast cancer cells. PLoS ONE 5 e10023. (doi:10.1371/journal.pone.0010023)
Qin J, Chen X, Xie X, Tsai MJ \& Tsai SY 2010a COUP-TFII regulates tumor growth and metastasis by modulating tumor angiogenesis. PNAS 107 3687-3692. (doi:10.1073/pnas.0914619107)

Qin J, Chen X, Yu-Lee LY, Tsai MJ \& Tsai SY $2010 b$ Nuclear receptor COUP-TFII controls pancreatic islet tumor angiogenesis by regulating vascular endothelial growth factor/vascular endothelial growth factor receptor-2 signaling. Cancer Research 70 8812-8821. (doi:10.1158/0008-5472.CAN-10-0551)

Riggs KA, Wickramasinghe NS, Cochrum RK, Watts MB \& Klinge CM 2006 Decreased chicken ovalbumin upstream promoter transcription factor II expression in tamoxifen-resistant breast cancer cells. Cancer Research 66 10188-10198. (doi:10.1158/00085472.CAN-05-3937)

Risbridger GP, Davis ID, Birrell SN \& Tilley WD 2010 Breast and prostate cancer: more similar than different. Nature Reviews. Cancer 10 205-212. (doi:10.1038/nrc2795)

Robinson CE, Wu X, Nawaz Z, Onate SA \& Gimble JM 1999 A corepressor and chicken ovalbumin upstream promoter transcriptional factor proteins modulate peroxisome proliferator-activated receptor- $\gamma 2 /$ retinoid $X$ receptor $\alpha$-activated transcription from the murine lipoprotein lipase promoter. Endocrinology 140 1586-1593. (doi:10.1210/en.140.4.1586)

Rodriguez JC, Ortiz JA, Hegardt FG \& Haro D 1997 Chicken ovalbumin upstream-promoter transcription factor (COUP-TF) could act as a transcriptional activator or repressor of the mitochondrial 3-hydroxy-3-methylglutaryl-CoA synthase gene. Biochemical Journal 326 587-592.

Rosa A \& Brivanlou AH 2011 A regulatory circuitry comprised of miR-302 and the transcription factors OCT4 and NR2F2 regulates human embryonic stem cell differentiation. EMBO Journal $\mathbf{3 0}$ 237-248. (doi:10.1038/emboj.2010.319)

Rufibach LE, Duncan SA, Battle M \& Deeb SS 2006 Transcriptional regulation of the human hepatic lipase (LIPC) gene promoter. Journal of Lipid Research 47 1463-1477. (doi:10.1194/jlr.M600082JLR200)

Sagami I, Tsai SY, Wang H, Tsai MJ \& O'Malley BW 1986 Identification of two factors required for transcription of the ovalbumin gene. Molecular and Cellular Biology 6 4259-4267.

Sauvaget D, Chauffeton V, Citadelle D, Chatelet FP, Cywiner-Golenzer C, ChambazJ, Pincon-Raymond M, Cardot P, Le Beyec J \& Ribeiro A 2002 Restriction of apolipoprotein A-IV gene expression to the intestine villus depends on a hormone-responsive element and parallels differential expression of the hepatic nuclear factor $4 \alpha$ and $\gamma$ isoforms. Journal of Biological Chemistry 277 34540-34548. (doi:10.1074/ jbc.M206074200)

Selva DM, Hogeveen KN \& Hammond GL 2005 Repression of the human sex hormone-binding globulin gene in Sertoli cells by upstream stimulatory transcription factors. Journal of Biological Chemistry 280 4462-4468. (doi:10.1074/jbc.M409616200)

Shenker N \& Flanagan JM 2012 Intragenic DNA methylation: implications of this epigenetic mechanism for cancer research. British Journal of Cancer 106 248-253. (doi:10.1038/ bjc.2011.550)

Shibata H, Nawaz Z, Tsai SY, O'Malley BW \& Tsai MJ 1997 Gene silencing by chicken ovalbumin upstream promoter-transcription factor I (COUP-TFI) is mediated by transcriptional corepressors, nuclear receptor-corepressor $(\mathrm{N}-\mathrm{CoR})$ and silencing mediator for retinoic acid receptor and thyroid hormone receptor (SMRT). Molecular Endocrinology 11 714-724. (doi:10.1210/me.11.6.714)

Shibata H, Kobayashi S, Kurihara I, Suda N, Yokota K, Murai A, Ikeda Y, Saito I, Rainey WE \& Saruta T 2004 COUP-TF and transcriptional co-regulators in adrenal steroidogenesis. Endocrine Research 30 795-801. (doi:10.1081/ERC-200044042)

Shimizu M, Cohen B, Goldvasser P, Berman H, Virtanen C \& Reedijk M 2011 Plasminogen activator uPA is a direct transcriptional target of the JAG1-Notch receptor signaling pathway in breast cancer. Cancer Research 71 277-286. (doi:10.1158/0008-5472.CAN-10-2523) 
Siddikuzzaman, Guruvayoorappan C \& Berlin Grace VM 2011 All trans retinoic acid and cancer. Immunopharmacology and Immunotoxicology 33 241-249. (doi:10.3109/08923973.2010.521507)

Sikora MJ, Cordero KE, Larios JM, Johnson MD, Lippman ME \& Rae JM 2009 The androgen metabolite $5 \alpha$-androstane- $3 \beta, 17 \beta$-diol (3ßadiol) induces breast cancer growth via estrogen receptor: implications for aromatase inhibitor resistance. Breast Cancer Research and Treatment 115 289-296. (doi:10.1007/s10549-008-0080-8)

Sikora MJ, Strumba V, Lippman ME, Johnson MD \& Rae JM 2012 Mechanisms of estrogen-independent breast cancer growth driven by low estrogen concentrations are unique versus complete estrogen deprivation. Breast Cancer Research and Treatment 134 1027-1039.

Srinivasan RS, Geng X, Yang Y, Wang Y, Mukatira S, Studer M, Porto MP, Lagutin O \& Oliver G 2010 The nuclear hormone receptor Coup-TFII is required for the initiation and early maintenance of Prox1 expression in lymphatic endothelial cells. Genes and Development 24 696-707. (doi:10.1101/gad.1859310)

Stanisic V, Lonard DM \& O'Malley BW 2010 Modulation of steroid hormone receptor activity. Progress in Brain Research 181 153-176. (doi:10.1016/S0079-6123(08)81009-6)

Stroup D \& Chiang JY 2000 HNF4 and COUP-TFII interact to modulate transcription of the cholesterol $7 \alpha$-hydroxylase gene (CYP7A1). Journal of Lipid Research 41 1-11.

Stylianou S, Clarke RB \& Brennan K 2006 Aberrant activation of Notch signaling in human breast cancer. Cancer Research 66 1517-1525. (doi:10.1158/0008-5472.CAN-05-3054)

Suzuki T, Moriya T, Darnel AD, Takeyama J \& Sasano H $2000 a$ Immunohistochemical distribution of chicken ovalbumin upstream promoter transcription factor II in human tissues. Molecular and Cellular Endocrinology 164 69-75. (doi:10.1016/S0303-7207(00)00242-2)

Suzuki T, Takahashi K, Darnel AD, Moriya T, Murakami O, Narasaka T, Takeyama J \& Sasano H $2000 b$ Chicken ovalbumin upstream promoter transcription factor II in the human adrenal cortex and its disorders. Journal of Clinical Endocrinology and Metabolism 85 2752-2757. (doi:10.1210/jc.85.8.2752)

Tang K, Xie X, Park JI, Jamrich M, Tsai S \& Tsai MJ 2010 COUP-TFs regulate eye development by controlling factors essential for optic vesicle morphogenesis. Development 137 725-734. (doi:10.1242/dev. 040568)

Tanimoto K, Liu Q, Grosveld F, Bungert J \& Engel JD 2000 Contextdependent EKLF responsiveness defines the developmental specificity of the human epsilon-globin gene in erythroid cells of YAC transgenic mice. Genes and Development 14 2778-2794. (doi:10.1101/gad.822500)

Thornton JW 2001 Evolution of vertebrate steroid receptors from an ancestral estrogen receptor by ligand exploitation and serial genome expansions. PNAS 98 5671-5676. (doi:10.1073/pnas.091553298)

Thornton JW, Need E \& Crews D 2003 Resurrecting the ancestral steroid receptor: ancient origin of estrogen signaling. Science $\mathbf{3 0 1}$ 1714-1717. (doi:10.1126/science.1086185)

Tobler NE \& Detmar M 2006 Tumor and lymph node lymphangiogenesis - impact on cancer metastasis. Journal of Leukocyte Biology 80 691-696. (doi:10.1189/jlb.1105653)

Tommasi S, Karm DL, Wu X, Yen Y \& Pfeifer GP 2009 Methylation of homeobox genes is a frequent and early epigenetic event in breast cancer. Breast Cancer Research 11 R14. (doi:10.1186/bcr2233)
Tsai SY \& Tsai M-J 1997 Chick ovalbumin upstream promotertranscription factors (COUP-TFs): coming of age. Endocrine Reviews 18 229-240. (doi:10.1210/er.18.2.229)

Vasyutina E \& Birchmeier C 2006 The development of migrating muscle precursor cells. Anatomy and Embryology 211 (Suppl 1) 37-41. (doi:10.1007/s00429-006-0118-9)

Vincent A, Omura N, Hong SM, Jaffe A, Eshleman J \& Goggins M 2011 Genome-wide analysis of promoter methylation associated with gene expression profile in pancreatic adenocarcinoma. Clinical Cancer Research 17 4341-4354. (doi:10.1158/1078-0432. CCR-10-3431)

Vittet D, Merdzhanova G, Prandini MH, Feige JJ \& Bailly S 2012 TGFss1 inhibits lymphatic endothelial cell differentiation from mouse embryonic stem cells. Journal of Cellular Physiology 227 3593-3602.

Widom RL, Rhee M \& Karathanasis SK 1992 Repression by ARP-1 sensitizes apolipoprotein AI gene responsiveness to RXR $\alpha$ and retinoic acid. Molecular and Cellular Biology 12 3380-3389.

Wu Q, Li Y, Liu R, Agadir A, Lee MO, Liu Y \& Zhang X 1997 Modulation of retinoic acid sensitivity in lung cancer cells through dynamic balance of orphan receptors nur77 and COUP-TF and their heterodimerization. EMBO Journal 16 1656-1669. (doi:10.1093/emboj/16.7.1656)

Yang C, Yu B, Zhou D \& Chen S 2002 Regulation of aromatase promoter activity in human breast tissue by nuclear receptors. Oncogene 21 2854-2863. (doi:10.1038/sj.onc.1205386)

You M, Fischer M, Cho WK \& Crabb D 2002 Transcriptional control of the human aldehyde dehydrogenase 2 promoter by hepatocyte nuclear factor 4: inhibition by cyclic AMP and COUP transcription factors. Archives of Biochemistry and Biophysics 398 79-86. (doi:10.1006/abbi.2001.2713)

You LR, Lin FJ, Lee CT, DeMayo FJ, Tsai MJ \& Tsai SY 2005 Suppression of Notch signalling by the COUP-TFII transcription factor regulates vein identity. Nature 435 98-104. (doi:10.1038/nature03511)

Yu RN, Ito M \& Jameson JL 1998 The murine Dax-1 promoter is stimulated by SF-1 (steroidogenic factor-1) and inhibited by COUPTF (chicken ovalbumin upstream promoter-transcription factor) via a composite nuclear receptor-regulatory element. Molecular Endocrinology 12 1010-1022. (doi:10.1210/me.12.7.1010)

Zeitoun K, Takayama K, Michael MD \& Bulun SE 1999 Stimulation of aromatase $\mathrm{P} 450$ promoter (II) activity in endometriosis and its inhibition in endometrium are regulated by competitive binding of steroidogenic factor-1 and chicken ovalbumin upstream promoter transcription factor to the same cis-acting element. Molecular Endocrinology 13 239-253. (doi:10.1210/me.13.2.239)

Zhang LJ, Liu X, Gafken PR, Kioussi C \& Leid M 2009 A chicken ovalbumin upstream promoter transcription factor I (COUP-TFI) complex represses expression of the gene encoding tumor necrosis factor $\alpha$-induced protein 8 (TNFAIP8). Journal of Biological Chemistry 284 6156-6168. (doi:10.1074/jbc.M807713200)

Received in final form 21 August 2012

Accepted 10 September 2012

Made available online as an Accepted Preprint

10 September 2012 